\title{
Media Pembelajaran Berbasis Aplikasi Android dalam Meningkatkan Keaksaraan
}

\author{
Riana Rahayu ${ }^{1 凶}$, Mustaji $^{2}$, Bachtiar Sjaiful Bachri ${ }^{3}$ \\ Pendidikan Dasar, Universitas Negeri Surabaya, Indonesia(1) \\ Teknologi Pendidikan, Universitas Negeri Surabaya, Indonesia(2) \\ Pengembangan Kurikulum, Universitas Negeri Surabaya, Indonesia(3) \\ DOI: $10.31004 /$ obsesi.v6i4.2409
}

\begin{abstract}
Abstrak
Keaksaraan salah satu perkembangan bahasa. Keaksaraan istillah yang digunakan untuk menjelaskan kemampuan anak dalam menggunakan aksara atau membaca dan menulis yang dikuasai sebelum anak belajar cara membaca dan menulis. Proses atau tahapan untuk melatih anak membaca lancar. Setelah anak siap membaca dan sudah memahami bentuk huruf dan bunyinya kemudian mengenal suku kata dan akhirnya menjadi kalimat. Penelitian ini menggunakan pendekatakan kualitatif deduktif dengan teknik kajian pustaka atau kajian literatur yang bersumber dari buku, jurnal dan literatur terdahulu seseuai dengan topik penelitian dalam kurun waktu sepuluh tahun terakhir 2011-2021 sebanyak 30 jurnal dan 8 buku. Penelitian ini bertujuan untuk mendeskrpsikan media pembelajaran berbasis android dalam meningkatkan keaksaraan. Hasil menunjukkan bahwa media pembelajaran berbasis android dapat meningkatkan keaksaraan. Hal ini bisa menjadi kajian keilmuan supaya pihak sekolah, orang tua atau peneliti lain bisa memaksimalkan kemampuan bahasa khususnya keaksaraan dengan memanfaatkan teknologi android pada media pembelajaran.
\end{abstract}

Kata Kunci: media pembelajaran; android; keaksaraan.

\begin{abstract}
Literacy is one of the developments of language. Literacy is the term used to describe a child's ability to use letters or to read and write that was mastered before the child learned how to read and write. The process or stages to train children to read fluently. After the child is ready to read and has understood the shape of the letters and their sounds, then they recognize syllables and finally become sentences. This study uses a deductive qualitative approach with a literature review technique or literature review sourced from previous books, journals and literature according to the research topic in the last ten years 2011-2021 as many as 29 journals and 9 books. This study aims to describe android-based learning media in improving literacy. The results show that android-based learning media can improve literacy. This can be a scientific study so that schools, parents or other researchers can maximize language skills, especially literacy by utilizing Android technology in learning media.
\end{abstract}

Keywords: instructional media; android; literacy

Copyright (c) 2022 Riana Rahayu, et al.

$\triangle$ Corresponding author :

Email Address : riana.20012@mhs.unesa.ac.id (Surabaya, Indonesia)

Received 9 November 2021, Accepted 26 February 2022, Published 27 February 2022 


\section{PENDAHULUAN}

Pendidikan anak usia dini ialah fondasi yang penting guna menunjang perkembangan dan pertumbuhan anak supaya mempunyai kesiapan belajar dalam memasuki pendidikan selanjutnya (Idris, 2015). Salah satu perkembangan yang perlu dimaksimalkan adalah bahasa. Sebagai bagian pertumbuhan bahasa anak, salah satunya adalah keaksaraan yang penting dalam pendidikan anak di masa sekolah. Kemampuan keaksaraan sangat diperlukan untuk memasuki jenjang pembelajaran di tingkatan yang lebih tinggi yaitu sekolah dasar. Kemampuan keaksaraan untuk memudahkan dalam membaca dimaknai sebagai kemampuan dalam memahami huruf atau aksara, membunyikan huruf atau rangkaian huruf- huruf( kata), dan menguasai arti atau maksud dari kata dan bacaan (Erika et al., 2021). Beberapa kegiatan keaksaraan seperti membaca, menulis, berhitung, sangat erat kaitanya dengan literasi, terdapat aspek perkembangan yang perlu ditingkatkan ialah pada aspek bahasa sasaran pencapaian bahasa anak dalam Satuan Tingkatan Pencapaian Pertumbuhan Anak( STTPA) usia dini ialah mengenal keaksaraan melalui huruf- huruf abjad, mengkomunikasikan serta menceritakan kembali (Hapidin et al., 2020). Hal ini selaras dengan Peraturan Menteri No. 137 Tahun 2014 tentang Standar nasional Pendidikan Anak Usia Dini (PAUD) menjelaskan bahwa lingkup perkembangan bahasa meliputi tiga ranah yaitu memahami bahasa, mengungkapkan bahasa dan keaksaraan. Salah satu ranah lingkup bahasa yang akan dibahas adalah kemampuan keaksaraan pada anak usia dini. Menurut Kamus Besar Bahasa Indonesia (KBBI) tahun 2021 keaksaraan adalah hal yang berkaitan dengan aksara membaca dan menulis. Pengembangan kemampuan keaksaraan pada saat ini berfokus pada dua bidang pengembangan yang terkait dengan pengembangan keaksaraan awal selama masa Taman Kanak-kanak, yaitu pengetahuan pengkodean dan huruf (atau alfabet). Fokus tersebut mencuatkan perspektif baru bahwa dengan adanya pengembangan kemampuan keaksaraan sejak usia dini mengalami keberhasilan dalam keterampilan berbahasa (Lori E. Skibbe et al., 2014)

Keaksaraan awal atau Pra-keaksaraan adalah isitilah yang digunakan untuk menjelaskan kemampuan anak dalam menggunakan aksara atau membaca dan menulis yang dikuasai sebelum anak belajar cara membaca dan menulis. Keaksaraan awal merupakan tatanan fondasi untuk mengusai kemampuan membaca dan menulis yang menyenangkan. Keadaan keaksaraan awal ini harus dikembangkan dengan baik di PAUD dan tidak dialihkan dengan penguasaan keaksaraan konvensional yang akan melelahkan anak dan menimbulkan pengalaman negatif terhadap membaca dan menulis (Sumardi, 2017). Tujuan utama mengenal keaksaraan yaitu sebagai persiapan dalam membaca dan menulis (Syefriani Darnis, 2018).

Kesiapan membaca menunjukkan kematangan perkembangan dan kesiapan anak untuk dapat membaca dengan mudah dan kompeten seperti mengenal huruf, menambah kosa kata baru dan memudahkan anak dalam belajar membaca untuk pendidikan selanjutnya (Astuti et al., 2021). Hal ini sangat diperlukan bagi anak usia 6 tahun, karena masa transisi dari TK ke SD berbeda dalam hal kebutuhan belajar. Kesiapan membaca anak harus dikembangkan oleh karena itu, pendidik harus memahami tingkat kesiapan membaca anak dengan melakukan suatu penilaian (Hapidin et al., 2020). Membaca pada usia dini pada hakikatnya merupakan sesuatu yang cukup sulit yang mengaitkan banyak hal, tidak hanya sekedar melafalkan tulisan, tetapi pula mengaitkan aktivitas visual, berfikir, serta metakognitifkan sebab proses membaca ialah proses menerjemahkan simbol tulisan( huruf) kedalam kata- kata lisan (Nahdi \& Yunitasari, 2019).

Anak- anak yang menampilkan kemampuan literasi berbentuk membaca semenjak dini hendak jadi pembaca yang suskes, penerapan literasi pada pendidikan anak usia dini bakal mempengaruhi pada keterampilan awal anak, penerapan literasi sejak dini akan memunculkan dampak yang longitudional untuk pertumbuhan kemampuan bahasa anak. Anak dengan keterlambatan literasi berkemungkinan juga akan terus terlambat pada anak seumuranya serta berdampak pada keahlian belajar membaca berikutnya (Novita \& Suyadi, 2020) 
Penelitian yang dilakukan oleh Hewi dan Shaleh (2020) terhadap hasil PISA Indonesia pada tahun 2018 berada di peringkat ke 74 dari 79 negara partisipan. Hasil ini tidak jauh berbeda dengan Hasil penilaian PISA pada tahun-tahun sebelumnya yaitu pemeringkatan Indonesia selalu berada di 10 besar terbawah. Temuan penelitian yang mendukung bahwa aspek yang dinilai oleh the programme for international student assesment salah satunya yaitu literasi membaca (bahasa) yang harus diberi stimulus secara konsen dan sistematis di lembaga-lembaga pendidikan anak usia dini serta melakukan perbaikan pada layanan stimulasi perkembangan dan penggunaan metode serta media pembelajaran yang relevan dengan tujuan pembelajaran di PAUD. Perkembangan bahasa masih menjadi masalah karena kurangnya stimulasi yang tepat diberikan pada anak. Seperti penggunaan media pada saat pembelajaran masih kurang maksimal yaitu kurangnya media pendukung untuk merangsang perkembangan bahasa anak dari semua komponen. Sebagian besar pembelajaran bersifat monoton hanya menggunakan lembar kerja siswa yang disediakan sekolah, artinya anak perlu di berikan inovasi media pembelajaran atau sumber lain yang tepat selain anak tidak bosan jua menimbulkan minat belajar yang tinggi (Bhayangkari et al., 2017).

Revolusi industrial 4.0 yang menandai datangnya masa digital ini, nyatanya tidak cuma pengaruhi kehidupan tiap hari manusia, namun juga di manfaatkan pada dunia pembelajaran, termasuk Pendidikan Anak Usia Dini(Taulany et al., 2020). Riset yang dilakukan oleh Fridberg melaporkan tentang proyek yang bertujuan buat memperluas penjelasan di saat ini ialah bagaimana teknologi tablet, bisa digunakan di prasekolah guna menunjang pendidikan kolaboratif fenomena sains kehidupan nyata. Kemampuan tablet untuk menunjang pendidikan sains berbasis penyelidikan kolaboratif serta pemikiran reflektif di prasekolah dilakukan melalui analisis aktivitas yang dipandu guru di bidangnya, termasuk anak- anak membuat fotografi timelapse serta film slowmation. Studi membuktikan kalau pemanfaatan media digital dalam pendidikan untuk anak usia dini ternyata membawa manfaat yang lumayan besar. Media pembelajaran salah satu faktor penting untuk meningkatkan kemudahan dalam proses belajar siswa, yang diharapkan dapat mempertinggi hasil belajar yang dicapainya (Fridberg et al., 2018). Beberapa hasil penelitian yang dilakukan terhadap penggunaan media dalam pembelajaran sampai pada kesimpulan, bahwa proses dan hasil belajar pada siswa menunjukkan adanya perbedaan yang signifikan antara pembelajaran yang menggunakan media dan yang tidak menggunakan media(Priantama, 2020).

Di era digital saat ini perlunya pembaharuan media pembelajaran mobile dimana tampilan bentuk visual yang menarik dan memberikan banyak manfaat bagi siswa dan pendidik terutama jenjang PAUD. Pemakaian aplikasi mobile pembelajaran pada proses mengajar juga membangkitkan motivasi belajar dan membawa dampak psikologi terhadap anak didik, dengan adanya aplikasi mobile bisa dimanfaatkan oleh anak usia dini dengan penggunaan android, sistem android mempunyai kelebihan di banding sistemn operasi yang lain bersifat open souce code sehingga memudahkan para pengembang untuk menciptakan modifikasi fitur pada sistem operasi android sesuai keinginan(Prasetyo et al., 2020)

\section{METODOLOGI}

Penelitian ini mengunakan pendekatan kuliatatif. Penelitian ini bertujuan untuk mengetahui media pembelajaran berbasis aplikasi android dalam meningkatkan kemampuan keaksaraan. Jenis penelitian ini adalah penelitan kepustakaan (library research), yaitu serangkaian penelitian yang berkenaan dengan metode pengumpulan data pustaka, atau penelitian yang obyek penelitiannya digali melalui beragam informasi kepustakaan (buku, ensiklopedi, jurnal ilmiah, koran, majalah, dan dokumen). Penelitian kepustakaan atau kajian literatur (literature review, literature research) merupakan penelitian yang mengkaji atau meninjau secara kritis pengetahuan, gagasan, atau temuan yang terdapat di dalam tubuh literatur berorientasi akademik (academic-oriented literature), serta merumuskan kontribusi teoritis dan metodologisnya untuk topik tertentu. 
Penelitian ini seluruhnya berdasarkan oleh studi literatur atau kajian kepustakaan (library reseach). Data yang di kumpulkan dan di analisis seluruhnya berasal literatur ataupun bahan dokumentasi, seperti halnya tulisan jurnal, media lain yang relevan. Data yang akan di kumpulkan dalam riset ini yaitu jenis data bersiat primer dan sekunder.

Sampel penelitian ini menggunakan sampel berupa hasil penelitan terdahulu terkait dengan bahasa fokus pada keaksaraan dengan rentang usia 5-6 tahun. Hasil penelitian terdahulu didapatkan dari artikel-artikel ilmiah yang telah di publikasikasikan dalam kurun waktu 2011-2021 sebanyak 30 artikel jurnal dan 8 buku.

Teknik pengumpulan data menggunakan metode studi literatur. Dimana sistem pengambilan data dalam penelitian ini bersumber dari buku-buku atau jurnal-jurnal yang akan di analisis berdasarkan permasalahan yang ada dan relevan. Teknik pengumpulan data yang digunakan penulis studi kepustkaan yaitu dengan cara mencari data yang berkaitan dengan permasalahan ataupun pembahasan yang relevan. Penelitian ini semua data-data yang relevan di kumpulkan dengan cara studi pustaka, studi literatur, dan pencarian data di internet.

Teknik analisis data yang penulis gunakan yaitu teknik analisa kualitatif dengan cara deduktif yaitu hal-hal atau teori yang bersifat umum atau menarik kesimpulan bersifat khusus. Selain itu dengan cara induktif yang berkaitan dengan fakta-fakta berbaai peristiwa khusus dan konkret kemudian menarik kesimpulan dari bersifat khusus ke umum. Ada empat langkah penelitian kepustakaan (Mestika Zed, 2008). Langkah penelitian disajikan pada gambar 1 .

$\begin{array}{cc}\begin{array}{c}\text { Mengumpulkan data } \\ \text { pustaka }\end{array} & \begin{array}{c}\text { Memuat catatan } \\ \text { penelitian }\end{array} \\ \begin{array}{c}\text { Membaca dan } \\ \text { menganalisis bahan } \\ \text { kepustakaan }\end{array} & \begin{array}{c}\text { Menelaah dan } \\ \text { mengolah sumber } \\ \text { sumber pustaka }\end{array}\end{array}$

\section{Gambar 1. Langkah-Langkah Penelitaian Kepustakaan}

\section{HASIL DAN PEMBAHASAN}

\section{Media Pembelajaran Berbasis Aplikasi Android}

Komunitas akademik internasional yakin bahwa perangkat seluler pintar terutama tablet atau seluler pintar yang terhubung dengan android dapat berfungsi sebagai perlengkapan penting untuk meningkatkan pembelajaran serta pengajaran, memungkinkan anak- anak prasekolah untuk mengeksplorasi konsep-konsep lanjutan yang sesuai dengan kelompok usia atau jenjang anak (Papadakis et al., 2018). Senada dengan pendapat (Satyaputra \& Aritonang, 2014) bahwa android adalah sebuah sistem operasi untuk smartphone dan tablet. Sistem operasi dapat diilustrasikan sebagai jembatan antara piranti (device) dan penggunaannya, sehingga pengguna dapat berinteraksi dengan device-nya dan menjalankan aplikasi-aplikasi yang tersedia pada device.

Aplikasi android adalah salah satu media pembelaaran jenis multimedia interaktif. Pembelajaran interaktif memiliki menu-menu khusus yang dapat diakses oleh user (anak PAUD) untuk memunculkan informasi berupa audio, visual maupun fitur lain yang diinginkan oleh pengguna. Salah satu pemanfaatan teknologi ke dalam pembelajaran yaitu menciptakan bahan ajar yang tepat guna sesuai dengan kebutuhan. Dalam kaitannya dengan pengembangan produk peran teknologi pembelajaran adalah untuk memfasilitasi dan meningkatkan kinerja agar tujuan pembelajaran dapat tercapai dengan cara "creating, using, and managing" yaitu dengan menciptakan, menggunakan dan mengontrol bahan ajar yang 
dikembangkan agar sesuai dengan fungsinya dan dapat memberi kemudahan dalam belajar (Putra \& Ishartiwi, 2015).

Media Pembelajaran berbasis Android diduga dapat membantu proses pembelajaran, dimana di dalam Media Pembelajaran Berbasis Android sudah terdapat materi berupa teori, gambar dan bentuk dapat diperlihatkan, video pembelajaran, dan yang paling penting adanya uji kompetensi yang berupa soal sebagai evaluasi untuk dapat melihat seberapa jauh kemampuan siswa dalam proses pembelajaran (Veri et al., 2020). Dalam android yang mempunyai keunggulan open source memudakan para pencipta aplikasi untuk memanfaatkan dalam bidang pendidikan. Seperti riset yang dikemukakan oleh Rais dan Riska mengenai aplikasi android yang memanfaatkan teknologi informasi komputer berbasis android sebagai media dalam mengarahkan minat karir siswa (sesuai rencana target capaian tahunan), akan difokuskan pada finalisasi produk. Validasi produk pada kelompok pengguna dan ahli menjadikan produk penelitian mendekati nilai guna (usefully) dan mudah dipahami siswa (friendly). Maka dari itu rancangan model aplikasi menekankan sesuai dengan ranah aspek perkembangan anak menciptakan suasana permainan yang dikemas dalam bentuk aplikasi belajar yang menyenangkan dan mudah di mainkan oleh anak atau pengguna (Rais \& Riska, 2018).

Dari uaraian diatas dapat disimpulkan bahwa media pembelajaran berbasis adroid dapat dimanfaatkan dalam dunia pendidikan sebagai sarana atau alat untuk memudahkan anak dalam memaksimalkan kemampuan. Selain itu dengan perpaudan ilmu pendidikan dan teknologi dapat memudahkan anak serta guru dalam kegiatan belajar mengajar karena mudah di akses dimana dan kapan saja.

\section{Kemampuan Keaksaraan}

Salah satu perkembangan yang harus dikembangkan adalah bahasa. Bahasa merupakan salah satu perkembangan yang harus dioptimalkan pada tingkat anak usia dini. Proses penerimaan bahasa yang melalui indera pendengaran adalah bahasa reseptif. Bahasa reseptif diperoleh dari pengalaman belajar anak yangmenghubungkan lambang bahasa yang diperolehnya melalui pendengaran yang bertujuan untuk memahami mimik dan nada suara yang kemudian mengerti arti kata(Alam \& Lestari, 2019)

Salah kemampuan berbahasa adalah dengan memberikan kegiatan yang mengembangkan dan memaksimalkan kemampuan keaksaraan anak. Whitehurst dan Lonigan, mendefinisikan kemampuan keaksaraan anak merupakan kemampuan yang dalam penerapannya bertujuan untuk mengembangkan keterampilan, memeroleh informasi serta pembiasaan pada keterampilan membaca dan menulis (Achmad \& Hasibuan, 2019)

Kemampuan keaksaraan adalah salah satu keterampilan bahasa yang sangat penting diajarkan pada anak sejak kecil yang melibatkan kegiatan mendengarkan, berbicara, membaca dan menulis. Salah satu kemampuan keaksaraan yang dikhususkan dalam penelitian ini yaitu dengan membaca (Agustin et al., 2021). Pendapat lain dari Haryanti Dwi \& Tejanignrum (2020) keaksaraan merupakan kemampuan menyebutkan simbol-simbol yang dikenal mengenal suara, huruf awal dari nama-nama benda, menyebutkan kelompok gambar yang memiliki bunyi huruf.

Meskipun kemampuan baca dan tulis (keaksaraan) terus dikembangkan sepanjang masa, pengalaman baca (keaksaraan) untuk anak usia empat dan lima tahun adalah meletakkan dasar yang penting bagi pengembangan baca tulis di masa depan. tujuan mengenal keaksaraan yaitu mengenalkan anak pada huruf dalam abjad, melatih keterampilan anak dalam mengubah huruf menjadi suara, dan keterampilan menyuarakan yang dapat dipraktekan ketika anak belajar membaca lanjut (Agustini \& Masudah, 2020).

Beberapa riset meyakinkan jika kemampuan membaca menentukan pencapaian perkembangan anak di jenjang pembelajaran berikutnya. Seperti pendapat dari Steinberg (dalam Ahmad Susanto, 2011) mengungkapkan membaca dini adalah membaca yang diajarkan secara terprogram kepada anak prasekolah. Program ini menumpukkan perhatian 
pada perkataan-perkataan utuh, bermakna dalam konteks pribadi anak-anak dan bahan yang diberikan melalui permainan dan kegiatan yang menarik sebagai perantaraan pembelajaran. Selain itu diperjelas oleh Dalman (2014) menjelaskan bahwa membaca permulaan meliputi 1) pengenalan bentuk huruf; 2) pengenalan unsur-unsur linguistik; 3) pengenalan hubungan/korespondensi pola ejaan dan bunyi (kemampuan menyuarakan bahan tertulis); 4) kecepatan membaca bertaraf lambat.

Membaca juga melatih anak untuk mengenal literasi sejak dini. Literasi dapat diartikan sebagai kemelekan huruf, mengenal tulisan, serta dapat membaca tulisan. Anak mampu berkomunikasi dengan lingkungan sekitar maka akan tumbuh kepercayaan anak dan dapat melakukan interaksi dan sosialisasi dengan lingkungan sekitarnya. Kemampuan literasi baik secara lisan maupun tulisan seperti membaca dan menulis merupakan kemampuan dasar yang harus dimiliki oleh setiap anak (Nahdi \& Yunitasari, 2019)

\section{Kompetensi Dasar Keaksaraan Anak Usia 5-6 Tahun}

Kompetensi dasar bahasa keaksaraan menurut peraturan menteri pendidikan No 160 tahun 2014 yang intinya PAUD wajib menyelenggarakan kurikulum 2013 PAUD, didalam peraturan menteri tentang kurikulum 2013 yaitu peraturan menteri pendidikan dan kebudayaan 137 tahun 2014 disebut bahwa PAUD memiliki standar yang merupakan satu kesatuan yang tidak dapat dipisahkan dalam pengelolaan penyelenggaraan PAUD yang menjadi acuan dalam pengembangan, implementasi dan evaluasi kurikulum PAUD. Kompetensi Dasar dan Target Kompetensi seperti tabel 1 dan 2.

Tabel 1. Kompetensi Dasar Keaksaraan Usia 5-6 Tahun

\begin{tabular}{|c|c|c|c|}
\hline No & Usia & Kompetensi Dasar & Target KD \\
\hline \multicolumn{4}{|c|}{ KD Pengetahuan dan Keterampilan } \\
\hline 3.12 & $\begin{array}{l}5-6 \\
\text { tahun }\end{array}$ & $\begin{array}{l}\text { Mengenal keaksaraan awal melalui } \\
\text { bermain }\end{array}$ & $\begin{array}{l}\text { Mengenal keaksaraan awal } \\
\text { melalui bermain }\end{array}$ \\
\hline 4.12 & & $\begin{array}{l}\text { Menunjukkan Kemampuan keaksaraan } \\
\text { awal dalam berbagai bentuk karya }\end{array}$ & $\begin{array}{l}\text { Menunjukkan } \\
\text { kemampuan } \\
\text { keaksaraan awal dalam } \\
\text { berbagai bentuk karya }\end{array}$ \\
\hline
\end{tabular}

Tabel 2. Indikator Pencapaian Perkembangan Keaksaraan Usia 5-6 Tahun

\begin{tabular}{ll}
\hline \multicolumn{1}{c}{ Indikator Capaian Perkembangan Usia 5- 6 Tahun } \\
\hline 1. & Menyebutkan simbol-simbol huruf yang dikenal \\
2. Mengenal suara huruf awal dari nama benda benda yang ada di sekitarnya. \\
3. Menyebutkan kelompok gambar yang memiliki bunyi/huruf awal yang sama \\
4. Memahami hubungan antara bunyi dan bentuk huruf \\
5. Membaca nama sendiri \\
6. Menuliskan nama sendiri \\
7. Memahami arti kata dalam cerita
\end{tabular}

\section{Tujuan Keaksaraan Anak Usia Dini}

Tujuan mengenalkan keaksaraan menurut pendapat Soejono (dalam Agustini \& Masudah, 2020) terdapat tujuan mengenalkan keaksaraan yaitu: a) mengenalkan anak pada huruf-huruf dalam abjad sebagai tanda suara atau bunyi; b) melatih keterampilan anak untuk mengubah huruf-huruf dalam kata menjadi suara; c) pengetahuan huruf-huruf dalam abjad dan keterampilan menyuarakan wajib untuk dapat dipraktekkan dalam waktu singkat ketika anak belajar membaca lanjut. Pendapat lain menegaskan dari Anderson dkk (dalam Dhieni, 2019) mengungkapkan membaca adalah suatu proses untuk memahami makna suatu tulisan. 
Proses yang dialami dalam membaca adalah berupa penyajian kembali dan penafsiran suatu kegiatan di mulai dari mengenali huruf, kata, ungkapan, frase, kalimat, dan wacana serta menghubungkannya dengan bunyi dan maknanya.

\section{Tahap-tahap kemampuan membaca}

Tahap-tahap kemampuan membaca menurut Steinberg (dalam Ahmad Susanto, 2011) yaitu a) Tahap timbulnya kesadaran terhadap tulisan. Tahap ini anak mulai belajar menggunakan buku dan menyadari bahwa buku penting; b) Tahap membaca gambar. Tahap ini Anak usia taman kanak-kanak telah dapat memandang dirinya sebagai pembaca, dan mulai melibatkan diri dalam kegiatan membaca, pura-pura membaca buku, memberi makna gambar; c) Tahap pengenalan bacaan. Tahap ini anak usia dini telah dapat menggunakan tiga sistem bahasa, seperti fonem (bunyi huruf), semantik (arti bahasa), dan sintaks (aturan kata atau kalimat) secara bersama-sama; d) Tahap membaca lancar. Tahap ini anak sudah dapat membaca lancar sebagai jenis buku yang berbeda dan bahanbahan yang berlangsung berhubungan dengan kehidupan sehari-hari. Sedangkan menurut Widyastuti (2017) yaitu 1) Tahap fantasi (magical stage) Tahap ini anak mulai berlajar menggunakan buku. Ia berpikir bahwa buku itu penting, membolak-balikan buku dan membawa buku kesukaannya; 2) Tahap pembentukan konsep diri (self concept stage) tahap ini anak memandang dirinya sebagai pembaca dan mulai memlibatkan diri dalam kegiatan membaca, pura-pura membaca buku, memberi makna pada gambar atau pengalaman sebelumnya dengan buku, menggunakan bahasa buku meskipun tidak cocok dengan tulisan; 3) Tahap membaca gambar, tahap ini anak menjadi sadar pada cetakan yang tampak serta dapat menemukan kata yang sudah dikenal, dapat mengungkapkan kata-kata yang memiliki makna dengan dirinya dapat mengulang kembali cerita yang tertulis, serta mengenal abjad; 4) Tahap pengenalan bacaan (take-off reader stage) Tahap ini mulai menggunakan tiga sistem isyarat (graphoponic, semantic, dan syntatic) secara bersama-sama. Anak tertarik pada bacaan, mulai mengingat kembali, berusaha mengenal tanda-tanda pada lingkungan serta membaca berbagai tanda.

\section{Media Pembelajaran Berbasis Aplikasi Android dalam Meningkatkan Kemampuan Keaksaraan}

Perkembangan teknologi pada saat seperti sekarang ini untuk memacu kemajuan dibidang informasi, semakin cepatnya perkembangan teknologi, didalam dunia pendidikan sangat diperlukan media pembelajaran melalui bidang IT. Sehubungan dengan hal itu dirasa penggunaan sistem dalam suatu pembelajaran sangat diperlukan, agar mengubah pembelajaran formal yang membosankan dan monton menadi pembelajarn yang edukatif dan menyenangkan melalui perantara game atau media interaktif yang mudah untuk anak(Fithri \& Setiawan, 2017)

Interaktivitas teks digital pada tablet layar sentuh mengundang klik dan manipulasi konten di layar. Kegiatan tersebut dapat berinteraksi dengan cara yang kurang lebih mendukung dengan dialog seputar cerita, dan penelitian telah menunjukkan bahwa hal itu dapat mengalihkan anak-anak (dan orang dewasa) dari konten dan menuju mekanisme media (Mangen et al., 2019). Pengenalan membaca pada anak harus dilakukan dengan cara yang menarik dan menyenangkan, tujuannya agar pesan yang ingin disampaikan oleh guru dapat ditangkap atau dicerna dengan mudah oleh anak (Winarti \& Suryana, 2020). Penggunaan media pembelajaran yang menarik bagi anak dapat menjadi titik awal bagi anak untuk mengenal huruf dan belajar membaca. Setelah anak mengenal huruf tersebut maka akan memudahkan anak untuk membaca permulaannya, dan untuk penggunaan media kartu surat akan memudahkan anak untuk mengingat bentuk huruf tersebut (Astuti et al., 2021).

Berdasarkan penelitian oleh Busran dan Fitriyah, dilakukan mengenai aplikasi belajar pra membaca pada anak prasekolah berbasis smartphone android menggunakan software pendukung Java Development Kit JDK IDE Eclipse, Android Software Development Kit (SDK) , Android Development Tool(ADT) yang dibuat menggunakan bahasa pemrograman java 
maka dapat disimpulkan bahwa software aplikasi dapat digunakan sebagai alat bantu ajar dalam bentuk game edukasi berbasis smartphone android dengan teknologi mobile learning (Sihotang, 2017). Riset berikutnya yang dilakukan oleh Setiawan bahwa aplikasi yang telah dibuat dengan platform android mempermudah penggunaan siswa dalam mengakses konten belajar dan bermain. Konten belajar dan bermain sudah cukup baik untuk membantu mengenalkan salah satunya adalah huruf-huruf. Aplikasi yang dibangun melalui android dapat membantu untuk kebutuhan di PAUD(Setiawan et al., 2018)

Hasil penelitian lain mengatakan bahwa kebutuhan media untuk menfasilitasi kemampuan keaksaraan dalam meningkatkan membaca anak adalah media educative game berbasis aplikasi android yang dapat membuat anak tertarik untuk memainkannya. Oleh karena itu, peneliti merancang android karena anak lebih tertarik dengan smartphone (Febriani et al., 2020). Penelitian yang dilakukan oleh Maria Kordaki dan Anthi Gousiou Makalah ini telah menyajikan studi tinjauan 10 tahun yang berfokus pada penyelidikan penggunaan Digital Card Games (DCGs) sebagai sarana pembelajaran dalam pendidikan dalam dekade (2003-2013). DCG konteks pembelajaran yang sesuai baik melalui permainan atau melalui konstruksi permainan di berbagai tingkat pendidikan dan berbagai pembelajaran mata pelajaran, dengan perpaduan Ilmu Komputer terbukti yang paling populer. Faktanya, DCG merupakan jenis permainan digital fleksibel yang menawarkan kerangka kerja tertentu - terdiri kartu dan aturan - di mana subjek pembelajaran tersebut dapat disesuaikan atau berubah. Hasilnya juga menegaskan bahwa desain DCG telah terinspirasi oleh logika permainan yang sudah dikenal, aspek fundamental dari sosial modern dan konstruktivis teori belajar dan beberapa hasil penting dari studi penelitian pendidikan sebelumnya serta banyaknya kemungkinan yang tersedia dari teknologi digital modern. Sebagian besar teknologi ini menampilkan elemen penting untuk penguatan sosial dan pembelajaran konstruktivis. Untuk tujuan ini, desainer DCG mengintegrasikan model modern seperti itu teknologi dan mencoba meningkatkan pengalaman berusaha membuat permainan lebih menarik, menarik, memotivasi, dan menarik untuk pemain dengan memanfaatkan teknologi yang tersedia dan menambahkan modalitas baru interaksi untuk membuat game inovatif yang dapat bersaing dengan tipe game seperti petualangan, permainan peran online multipemain masif, realitas virtual, dan lain-lain yang digunakan sebagai sarana pendidikan(Kordaki \& Gousiou, 2017).

\section{Kelebihan Media Pembelajaran Aplikasi Android Terhadap Kemampuan Keaksaraan}

Hubungan antara media dengan teknologi pendidikan tidak dapat di lepaskan. Penggunaan media dalam kegiatan pendidikan pembelajaran merupakan bagian dari teknologi pendidikan Sukiman (2012) kelebihan media pembelajaran berbasis aplikasi android tidak hanya digunakan pada anak-anak normal tetapi sebaliknya. Seperti penelitian yang dilakukuan oleh Anas dan Mahayuddin merancang sebuha aplikasi anak autis untuk belajar huruf dengan bantuan elemen interaktif dan peningkatan augmented reality. Elemen yang menarik dari aplikasi tersebut disebut multimedia interaktif. Tampilan visual, animasi, video, audio dan warna-warni dapat diintegrasikan dalam sebuah aplikasi. Visualisasi interaktif dan sistematis disarankan sebagai aspek utama pengajaran untuk anak-anak austictic untuk menarikperhatian. Mengintegrasikan sistem pembelajaran visual dan audio tidak membebani kapasitas memori kerja anak autis yang terbatas sehingga multimedia interaktif van terbukti menjadi solusi yang bagus untuk autis split attention (Anas \& Mahayuddin, 2017). Kelebihan lain dari hasil validasi ahli media menunjukkan bahwa secara umum produk seperti game berbasis android memiliki nilai baik. Dari keseluruhan aspek penilaian, yaitu interface (tampilan), tingkat kesukaran, keajegan program, keberfungsian hyperlink (tautan), kecepatan, interaktivitas, dan fungsi yang muncul suara memiliki nilai baik dan sedang (Purnama, 2016). 


\section{Kekurangan Media Pembelajaran Aplikasi Android Terhadap Kemampuan Keaksaraan}

Dari penelitian analisis yang dilakukan di negara Yunani hasil studi tidak terpenuhi semua yang dibutuhkan dalam pembelajaran. Sebagian besar aplikasi bertujuan untuk mengajari anak-anak dasar-dasar tentang angka dan huruf. Secara keseluruhan, mereka bergaya drill-and-practice, pada anak yang mempunyai tingkat keterampilan berpikir yang rendah, sehingga mendorong pembelajaran hafalan, dan tidak dapat berkontribusi pada pemahaman konseptual yang lebih dalam tentang konsep-konsep tertentu (Papadakis et al., 2018)

\section{SIMPULAN}

Media pembelajaran berbasis aplikasi android dapat meningkatkan kemampuan keaksaraan. Terbukti secara praktis bahwa media berbasis android memudahkan anak dalam menggunakan. Selain itu pembelajaran dikemas dengan menarik sesuai dengan aspek perkembangan anak dengan prinsip belajar anak yaitu belajar melalui bermain. Disisi lain untuk meningkatkan tren pembelajaran berbasis teknogi sesuai dengan perkembangan zaman.

\section{UCAPAN TERIMA KASIH}

Ucapan terima kasih peneliti ucapkan kepada dosen pembimbing yang telah menyempurnakan tulisan ini dan beberapa referensi yang peneliti gunakan

\section{DAFTAR PUSTAKA}

Achmad, I. B., \& Hasibuan, R. (2019). Pengaruh Papan Permainan Kata (Paperta) Terhadap Kemampuan Keaksaraan Anak Kelompok B Usia 5-6 Tahun Di Tk Aisyiyah Bustanul $\begin{array}{lllll}\text { Athfal } & 25 & \text { Surabaya. } & \text { PAUD } & \text { Teratai, }\end{array}$ https://doi.org/10.24853/instruksional.1.1.25-31

Agustin, M., Inten, D. N., Permatasari, A. N., \& Mulyani, D. (2021). Strategi Guru PAUD dalam Mengembangkan Kecerdasan Interpersonal Anak Usia Dini di Saat Belajar dari Rumah. Jurnal Obsesi: Jurnal Pendidikan Anak Usia Dini, 5(2), 1997-2007. https://doi.org/10.31004/obsesi.v5i2.1055

Agustini, D. R., \& Masudah, D. (2020). Pengaruh Media Dadu Putar Terhadap Kemampuan Keaksaraan Anak Kelompok B. Jurnal PAUD Teratai, 9(1).

Ahmad Susanto. (2011). Perkembangan Anak Usia Dini: Pengantar Dalam Berbagai Aspeknya. Kencana Prenadamedia Group.

Alam, S. K., \& Lestari, R. H. (2019). Pengembangan Kemampuan Bahasa Reseptif Anak Usia Dini dalam Memperkenalkan Bahasa Inggris melalui Flash Card. Jurnal Obsesi : Jurnal Pendidikan Anak Usia Dini, 4(1), 284. https:/ / doi.org/10.31004/obsesi.v4i1.301

Ana Widyastuti. (2017). Kiat Jitu Anak Gemar Baca Tulis. PT Elex Media Komputindo.

Anas, \& Mahayuddin. (2017). Aiding autistic children learn Arabic through developing an engaging user-friendly android app. IIOAB Journal, 8, 87-90. http://www.embase.com/search/results?subaction=viewrecord\&from=export\&id= $\underline{\mathrm{L} 619462759}$

Astuti, A. W., Drupadi, R., \& Syafrudin, U. (2021). Hubungan Penggunaan Media Kartu Huruf dengan Kemampuan Membaca Permulaan Anak Usia 5-6 Tahun. KINDERGARTEN: Journal of Islamic Early Childhood Education, 4(1), 73-81.

Bhayangkari, K., Kendal, G. B., Sari, D. K., H, S. S. D., \& Tasu, N. (2017). Application of Media Booklet to Improve Language Development (initial reading) on Children in Kindergarten Kemala Group B Bhayangkari 34 Kendal. Indonesian Journal of Early Childhood Education Studies, 6(2), 120-126.

Dalman. (2014). Keterampilan Membaca. Rajawali Pers.

Dhieni, N. (2019). Metode Pengembangan Bahasa. Universitas Terbuka Kementrian Riset Teknologi dan Pendidikan Tinggi. 
Erika, E., Agrina, A., Novita, S., \& Komariah, M. (2021). Pengaruh Lingkungan Literasi di Kelas terhadap Kemampuan Membaca Permulaan Anak. Jurnal Obsesi : Jurnal Pendidikan Anak Usia Dini, 6(1), 252-260. https:// doi.org/10.31004/obsesi.v6i1.1225

Febriani, A. S., Mulyana, E. H., \& Rahman, T. (2020). Pengembangan Educative Game Berbasis Aplikasi Android Untuk Memfasilitasi Keterampilan Membaca Anak Usia 5-6 Tahun. Jurnal Paud Agapedia, 2(2), 187-196. https://doi.org/10.17509/jpa.v2i2.24544

Fithri, D. L., \& Setiawan, D. A. (2017). Analisa Dan Perancangan Game Edukasi Sebagai Motivasi Belajar Untuk Anak Usia Dini. Simetris: Jurnal Teknik Mesin, Elektro Dan Ilmu Komputer, 8(1), 225-230. https:// doi.org/10.24176/ simet.v8i1.959

Fridberg, M., Thulin, S., \& Redfors, A. (2018). Preschool children's Collaborative Science Learning Scaffolded by Tablets. Research in Science Education, 48(5), 1007-1026. https://doi.org/10.1007/s11165-016-9596-9

Hapidin, H., Nasution, R. H., \& Fridani, L. (2020). Pengaruh Pembelajaran ICT dan Minat Belajar terhadap Kesiapan Membaca Anak Usia Dini. Jurnal Obsesi : Jurnal Pendidikan Anak Usia Dini, 4(2), 733. https:// doi.org/10.31004/obsesi.v4i2.411

Haryanti Dwi, \& Tejanignrum, D. (2020). Keaksaraan Awal Anak Usia Dini. Pekalongan (Teori dan Praktis Calistung Menjadi Menyenangkan) (M. Nasarudin (ed.)). PT Nasya Expanding Management.

Hewi, L., \& Shaleh, M. (2020). Refleksi Hasil PISA (The Programme For International Student Assesment): Upaya Perbaikan Bertumpu Pada Pendidikan Anak Usia Dini). Jurnal Golden Age, 4(01), 30-41. https:/ / doi.org/10.29408/iga.v4i01.2018

Kordaki, M., \& Gousiou, A. (2017). Digital card games in education: A ten year systematic review. Computers and Education, 109, 122-161. https://doi.org/10.1016/j.compedu.2017.02.011

Lori E. Skibbe, Connor, C. M., Morrison, F. J., \& Jewkes, A. M. (2014). Schooling effects on preschoolers' self-regulation, early literacy, and language growth. Bone, 23(1), 42-49. https://doi.org/10.1016/j.ecresq.2010.05.001

Mangen, A., Hoel, T., Jernes, M., \& Moser, T. (2019). Shared, dialogue-based reading with books vs tablets in early childhood education and care: Protocol for a mixed-methods intervention study. International Journal of Educational Research, 97(July), 88-98. https:// doi.org/10.1016/j.ijer.2019.07.002

Meity H Idris. (2015). Strategi Pembelajaran Yang Menyenangkan (Implementasi Pada Pendidikan Anak Usia Dini. PT Luxima Metro Media.

Mestika Zed. (2008). Metode Penelitian Kepustakaan. Yayasan Obor Indonesia.

Nahdi, K., \& Yunitasari, D. (2019). Literasi Berbahasa Indonesia Usia Prasekolah: Ancangan Metode Dia Tampan dalam Membaca Permulaan. Jurnal Obsesi : Jurnal Pendidikan Anak Usia Dini, 4(1), 446. https:// doi.org/10.31004/obsesi.v4i1.372

Novita, C. C., \& Suyadi, S. (2020). Penggunaan Mainan Kartu Kata Membaca Berputar Berbasis Teknologi Untuk Anak Usia Dini. Aulad: Journal on Early Childhood, 3(3), 132-138. https://doi.org/10.31004/aulad.v3i3.82

Papadakis, S., Kalogiannakis, M., \& Zaranis, N. (2018). Educational apps from the Android Google Play for Greek preschoolers: A systematic review. Computers and Education, 116, 139-160. https:// doi.org/10.1016/j.compedu.2017.09.007

Prasetyo, F., Rachmatsyah, A. D., Nur, J., \& Adam, F. (2020). Penerapan Aplikasi Android Pengenalan Huruf Hijaiyah Metode Waterfall Pada Paud Al Fina. Jurnal Sisfokom (Sistem Informasi Dan Komputer), 9(3), 412-419. https:// doi.org/10.32736/sisfokom.v9i3.883

Priantama, R. (2020). Implementasi Algoritma Sift Pada Aplikasi Media Pembelajaraan Pendidikan Anak Usia Dini (Paud) Berbasis Augmented Reality Melalui Android. 6, 123. https://journal.uniku.ac.id/index.php/buffer

Purnama, S. (2016). Pengembangan Game Wazan Berbasis Android. Al Athfal: Jurnal Pendidikan Anak, 1(2), 9-19. 
DOI: 10.31004/obsesi.v6i4.2409

Putra, L. D., \& Ishartiwi, I. (2015). Pengembangan Multimedia Pembelajaran Interaktif Mengenal Angka Dan Huruf Untuk Anak Usia Dini. Jurnal Inovasi Teknologi Pendidikan, 2(2), 169-178. https:// doi.org/10.21831/tp.v2i2.7607

Rais, M., \& Riska, M. (2018). Pembelajaran Interaktif Edu-Game Pengenalan Profesi Berbasis Android Pada Siswa Paud. Jurnal Psikologi Pendidikan Dan Konseling: Jurnal Kajian Psikologi Pendidikan Dan Bimbingan Konseling, 4(1), 38. https://doi.org/10.26858/jpkk.v4i1.3645

Satyaputra, A., \& Aritonang, E. M. (2014). Biginning Android Programmin with ADT Bundle. Elek Media Koputindo.

Setiawan, A., Setiyaningsih, T., \& Triwibowo, T. (2018). Perancangan Mobile Application Berbasis Android Untuk Menunjang Kemampuan Kognitif Dan Psikomotorik Siswa Paud. Network Engineering Research Operation, 4(1), 37-45. https://doi.org/10.21107/nero.v4i1.110

Sihotang, R. P. (2017). Perancangan Permainan (Game) Edukasi Belajar Membaca Pada Anak Prasekolah Berbasis Smartphone Android (Studi Kasus : Taman Kanak-Kanak Ikal Iqra Padang Selatan). Jurnal Teknoif, 3, 1. https://doi.org/10.21063/JTIF

Sukiman. (2012). Pengembangan Media Pembelajaran. PT Pustaka Insan Madani.

Sumardi, E. (2017). Pengembangan Keaksaraan Awal Pada Anak Usia 5 - 6 Tahun Melalui Buku Cerita Budaya Lokal. In Kementrian pendidikan dan kebudayaan Balai Pengembangan Pendidikan Anak Usia Dini Dan Masyarakat Nusa Tenggara Barat. http:/ /e-journal.hamzanwadi.ac.id

Syefriani Darnis. (2018). Aplikasi Montessori Dalam Pembelajaran Membaca, Menulis Dan Berhitung Tingkat Permulaan Bagi Anak Usia Dini. Jurnal Caksana - Pendidikan Anak Usia Dini, 1(1), 1-10. https://doi.org/10.31326/jcpaud.v1i01.3

Taulany, H., Putra, L. V., \& Wibisono, I. S. (2020). Media Tangram Geometri "Let's Be Healthy" Berbasis Android untuk Meningkatkan Kemampuan Berpikir Geometri Anak Usia Dini. Jurnal Obsesi: Jurnal Pendidikan Anak Usia Dini, 4(2), 676. https://doi.org/10.31004/obsesi.v4i2.365

Veri, J., Surmayanti, S., \& Andini, S. I. (2020). Perancangan Dan Pembuatan Media Pembelajaran Berbasis Android Pada Mata Pelajaran Iqra (Studi Kasus PAUD/TK di Padang). Jurnal Pti (Pendidikan Dan Teknologi Informasi, 7(2), 1-9. https://doi.org/10.35134/jpti.v7i2.28

Winarti, W., \& Suryana, D. (2020). Pengaruh Permainan Puppet Fun terhadap Kemampuan Membaca Anak Usia Dini. Jurnal Obsesi : Jurnal Pendidikan Anak Usia Dini, 4(2), 873. https://doi.org/10.31004/obsesi.v4i2.462 